\title{
Glauconitic siltstone as a multi-nutrient fertilizer for Urochloa brizantha cv. Marandú
}

\author{
Isabel Cristina Acciardi Violatti, Camila de Andrade Carvalho Gualberto*, Luiz Henrique Silveira, Gustavo \\ Alves Santos, Bárbara Campos Ferreira, Pedro Magno Mendes Machado, Hamilton Seron Pereira
}

Institute of Agricultural Sciences, Federal University of Uberlândia, Uberlândia, Brazil

*Corresponding author: camila_carvalho03@hotmail.com

\begin{abstract}
Potassium (K) is one of the most absorbed nutrients by forage plants and it is found at low levels in tropical soils, requiring large amounts of fertilizers. The use of glauconitic siltstone as multi-nutrient fertilizers is an economic alternative to improve pasturebased production systems due to their low-cost production and long-term nutrient release. This study evaluated the effect of the glauconitic siltstone (GS) powder on three successive crops of Urochloa brizantha cv. Marandú (Syn. Brachiaria brizantha). Two experiments were carried out under greenhouse conditions, one using a Typic Dystrustox and the other a Typic Quartzipsamment. Both experiments were arranged in a completely randomized design with one factor, i.e., five glauconitic siltstone doses $(0,5,20$, 40 , and $80 \mathrm{mg} \mathrm{dm}^{-3}$ of $\mathrm{K}_{2} \mathrm{O}$ ) and four replications. In addition, three additional treatments were used, as potassium chloride, wollastonite and manganese sulfate at doses of $80 \mathrm{mg} \mathrm{dm}^{-3}$ of $\mathrm{K}_{2} \mathrm{O}, 270 \mathrm{mg} \mathrm{dm}^{-3}$ of silicon (Si) and $2 \mathrm{mg} \mathrm{dm}^{-3}$ of manganese (Mn), respectively. The sources were incubated for 60 days on the two soil types and, after the incubation period, Urochloa brizantha plants were grown. Three consecutive cuts were performed at 68, 104 and 168 days after sowing. The application of the GS in tropical soils promoted increases in plant dry matter, as well as K, Si and Mn levels in soil samples and accumulated in plants. In general, greater effects were obtained following the application of GS after consecutive cropping cycles due to its long-term release. Results described in this study provide an important understanding of the use of glauconitic siltstone as multi-nutrient fertilizers in tropical soils, being an efficient alternative to improve soil fertility and increase tropical pasture productivity.
\end{abstract}

Keywords: forage plants; manganese; plant nutrition; potassium; rock powder; silicon.

Abbreviations: $\mathrm{AEI} \_$agronomic efficiency index; DAS_days after sowing; DM_plant dry matter; GS_glauconitic siltstone; $\mathrm{KCl} \_$potassium chloride; $\mathrm{MnSO}_{4}$ manganese sulfate.

Introduction

Pasture-based production systems are the most practical and economical cattle feeding management (Dias-Filho, 2014), ensuring a low-cost livestock production to feed the growing world population (Cerri et al., 2016). However, despite efforts to maintain pasture productivity, progressive degradation is often reported to occur after about 5-15 years of pasture use (Asner et al., 2004) and, consequently, a reduction of the land value and delaying of animals slaughter age (Peron and Evangelista, 2004).

One of the main causes of pasture degradation has been linked to soil fertility declining due to nutrient removal caused by the unsuitable farming process. In this regard, nutrient supply is an important factor for pasture production, considering that the nutrient availability has a great influence on the plant nutrition and on cattle food quality (Bonfim-da-Silva; Monteiro, 2006). Moderate inputs of fertilizers are typically applied to address soil chemical deficiencies in improved pastures (Miles et al., 2004), especially in tropical areas, e.g. Brazilian pastures. Yet the use of soluble fertilizers being a good initial investment to increase tropical pasture productivity, the majority of pastures degrade after only a few years if not properly maintained with periodic inputs of fertilizer (Fonte et al., 2014).

Potassium (K) is one of the most absorbed nutrients for forage plants (e.g. Brachiaria spp.) and it is found at low levels in tropical soils, requiring large amounts of fertilizers. More than $90 \%$ of Brazilian potash needs is imported to supply the nutrient demand since the country presents poor quality and small-sized $\mathrm{K}$ soluble reserves (Oliveira et al., 2017), which considerably increase the costs of food production in the country.

Since livestock farming is developed with low investments and $\mathrm{K}$ plays an important role in the correct pasture management, alternative sources of this nutrient are frequently searched. Recent investigations suggest that the use of K-rich rocks may increase the long-term $\mathrm{K}$ contents in soils (Zörb et al., 2014). The direct use of glauconitic siltstone can be a viable, economical and ecological alternative, given its low production cost and long-term release.

Glauconitic siltstone is an example of K-rich rock which may increase soil fertility in the medium to long-term, according to their solubility and reaction with soil. Glauconitic provides $\mathrm{K}_{2} \mathrm{O}$ contents ranging from 7 to $14 \mathrm{dag} \mathrm{dm}^{-3}$ and no chloride 
(Cl) concentration, which allows it to be used in organic agriculture. These rocks also present other 68 elements, including silicon (Si) and manganese $(\mathrm{Mn})$, with a potential to be used not only as a $\mathrm{K}$ fertilizer, but as a multi-nutrient fertilizer. Additionally, the nutrient release from this fertilizer is slow and gradual, reducing losses by leaching and favoring a long-term release.

This study evaluated the effect of the glauconitic siltstone powder on three successive crops of Urochloa brizantha cv. Marandú (Syn. Brachiaria brizantha). Owing to its capability to supply $\mathrm{K}, \mathrm{Si}$ and $\mathrm{Mn}$ to plants, while increasing forage production, we expect to promote an alternative $\mathrm{K}$ source.

\section{Results and discussion}

\section{Plant dry matter (DM) and agronomic efficiency index (AEI)}

The effects of GS on Urochloa brizantha plant DM after three consecutive cuts, as compared with $\mathrm{KCl}$, are shown in Fig 1. At 68 and 104 DAS, the application of GS resulted in increases in plant DM, yet the effects are not comparable with the ones obtained with the application of $\mathrm{KCl}(80 \mathrm{mg}$ $\mathrm{dm}^{-3}$ of $\mathrm{K}_{2} \mathrm{O}$ ) (Fig $1 \mathrm{a}$ and $1 \mathrm{~b}$ ). Greater DM values following the application of $\mathrm{KCl}$ after the first two plant cuts are related to the great solubility of the standard source, since this salt is water soluble and readily available to plants (Prakash and Verma, 2016). However, at 168 DAS, higher DM values were obtained with the application of GS (20,40, and $80 \mathrm{mg} \mathrm{dm}^{-3}$ of $\mathrm{K}_{2} \mathrm{O}$ ) when compared to $\mathrm{KCl}$ (Fig 1c). The application of slow-release $\mathrm{K}$ fertilizers, such as the GS, can supply crop demand for nutrients after consecutive cycles (Resende et al, 2006), as well as minimize losses of $\mathrm{K}$ by leaching. Since $\mathrm{K}$ presents a small hydrated ion size, the application of soluble $\mathrm{K}$-sources (e.g. $\mathrm{KCl}$ ) results in a low retention in soil's cation-exchange capacity (CEC) (Yamada and Roberts, 2005). Thus, the nutrient release from this fertilizer is slow and gradual, which reduces losses by leaching and favors a long-term release (Martins et al., 2015). Such results are especially relevant in tropical areas with soil fertility constraints.

Previous studies have also indicated that crops fertilized with high $\mathrm{KCl}$ doses can present great $\mathrm{Cl}$ accumulation in leaves, promoting soil salinity (Silva et al., 2001) and, as a consequence, water stress to plants (Cruz et al., 2006). In fact, increases in plant DM after consecutive cycle crops with the application of GS may be related to both slow-release characteristic and low salinity potential. In addition, this alternative source presents $\mathrm{Mn}$ in its composition, which is an essential nutrient for normal growth and development of most plants (Twyman, 1951) and Si, a beneficial element extracted in large amounts by grasses, especially in intensive cropping (Meena et al., 2014).

The effect of GS application on plant development can also be noted analyzing agronomic efficiency index (AEI) values (Fig 2). In general, smaller AEI values after the first two cuts were obtained after GS application (values lower than $100 \%)$. On the other hand, after the third cut, the GS source presented greater agronomic efficiency, being a good alternative of long-term fertilizer.

\section{$K$ levels on soil and accumulated in plants}

The application of increasing doses of the GS increased the levels of $\mathrm{K}$ on soil and accumulated in Urochloa brizantha plants (Fig 3), with a greater effect after the third plant cut (Fig 3d). At 168 DAS, the application of GS in clayey soil at the dose of $20 \mathrm{mg} \mathrm{dm}^{-3}$ resulted in higher $\mathrm{K}$ accumulated levels in Urochloa brizantha plants than $\mathrm{KCl}\left(20 \mathrm{mg} \mathrm{dm}^{-3}\right)$ treatments, even the glauconitic siltstone fertilizer being applied at a dose four times lower than the standard source (Fig 3d). Potash is one of the most important fertilizers for agricultural lands because it improves water retention, yield, nutrient value, taste, colour, texture, and disease resistance of food crops (Geman et al., 2015). Thus, the GS can be used as a sustainable source of $\mathrm{K}$ for long-term crops, as this fertilizer releases $\mathrm{K}_{2} \mathrm{O}$ slowly and reduces the demand for chemical fertilizers. Increases in plant $\mathrm{K}$ levels following the application of the GS are related to the chemical composition of this source, since the applied product presents $100 \mathrm{~g} \mathrm{dm}^{-3}$ of $\mathrm{K}$. The GS K-content can be attributed to the occurrence of glauconite in the rock, which it is a hydrated lamellar silicate of $\mathrm{K}$ and $\mathrm{Fe}$ composed of tetrahedral and octahedral leaves (Gamero et al., 2004).

The values of recovery of $\mathrm{K}$-applied also indicate the lowsolubility of the GS (Fig 4). In general, the application of $\mathrm{KCl}$ both in clayey and sandy soils promoted a higher recovery of $\mathrm{K}$-applied than the GS at 68 and 104 DAS. On the other hand, at $168 \mathrm{DAS}, 1.1 \%$ and $2.5 \%$ of recovery of K-applied were obtained after GS application, whereas the values after the $\mathrm{KCl}$ application were equal to $0.9 \%$ and $0.7 \%$, both in clayey and sandy soil, respectively.

\section{Si and Mn levels on soil and accumulated in plants}

Besides increasing the unnecessary soil and accumulated $\mathrm{K}$ levels, the application of GS also improved the levels of Si and $\mathrm{Mn}$ on soil and accumulated in plants (Fig 5 and Fig 6). Increases in plant Si levels were obtained after the three plant cuts, yet the effects are not comparable with the ones obtained with equivalent doses of Wollastonite, due to the greater solubility of the standard Si source (Fig 5). Tropical soils (e.g. oxisol) are depleted of soluble sources of Si due to weathering and leaching associated with high rainfall and temperatures, leading to marginal or deficient Si levels in plants (Keeping, 2017). Thus, yield responses to the application of low soluble Si fertilizers have been recorded in these soils, which have significant potential in supplying $\mathrm{Si}$ over time, especially for crop species that accumulate $\mathrm{Si}$ to levels $>1.0 \%$ shoot Si dry mass (Ma and Takahashi, 2002), as grasses and forage species.

Increases on soil and plant accumulated $\mathrm{Mn}$ levels were also obtained following the application of increases doses of GS (Fig 6). In general, a greater effect of GS on plant accumulated Mn levels was observed at 168 DAS due to the low solubility of this source, as previously discussed (Fig 6d). Since soils cultivated with forage crops show very low $\mathrm{Mn}$ levels, it is important to focus on Mn-fertilization because of the importance of the nutrient in animal organisms regarding metabolism of carbohydrates and lipids (Ubavić et al., 2008). In addition, Mn plays a key role in many plant oxidation-reduction processes, activation of enzymes, photosynthesis, metabolism of carbohydrates, and synthesis of plant pigments (Burnell et al., 1988). 
Table 1. Chemical composition of glauconitic siltstone, $\mathrm{KCl}$, Wollastonite, and $\mathrm{MnSO}_{4}$.

\begin{tabular}{|c|c|c|c|c|c|}
\hline \multirow{3}{*}{ Source } & \multicolumn{2}{|r|}{$\mathrm{K}_{2} \mathrm{O}$} & \multicolumn{2}{|r|}{$\mathrm{Si}$} & \multirow[t]{2}{*}{$\mathrm{Mn}$} \\
\hline & Total & Soluble & Total & Soluble & \\
\hline & \multicolumn{5}{|c|}{$\mathrm{g} \mathrm{dm}^{-3}$} \\
\hline Glauconitic Siltstone & 100 & 5 & 270 & 5 & 0.5 \\
\hline $\mathrm{KCl}$ & 600 & 600 & - & - & - \\
\hline Wollastonite & - & - & 230 & 120 & - \\
\hline $\mathrm{MnSO}_{4}$ & - & - & - & - & 310 \\
\hline
\end{tabular}

Total and solube $\mathrm{K}_{2} \mathrm{O}$ : Lorentzen and Kingston (1996). Total and available Si: Korndorfer et al. (2004). Total Mn: MAPA (2007).

(a)

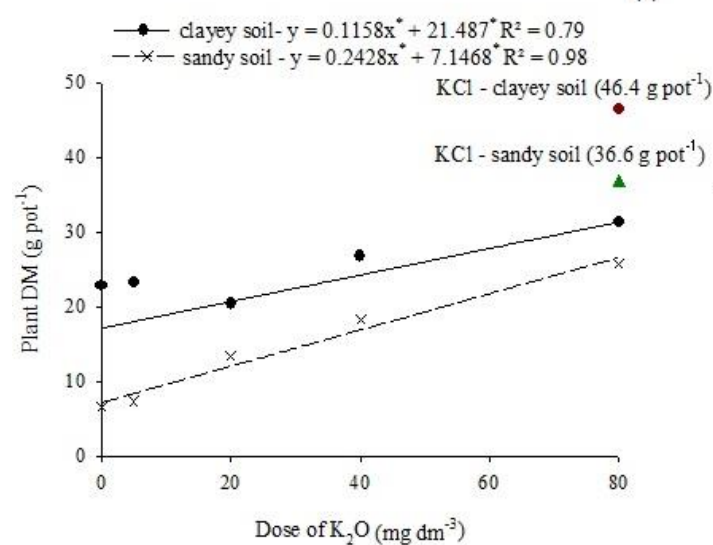

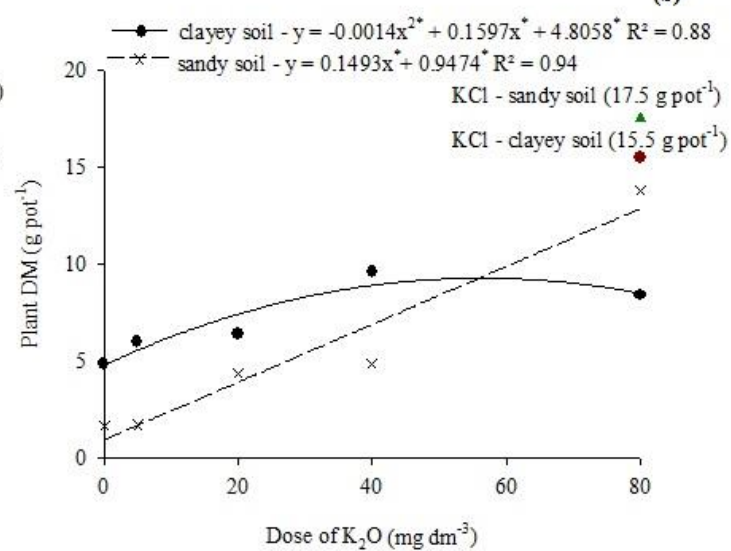

(c)

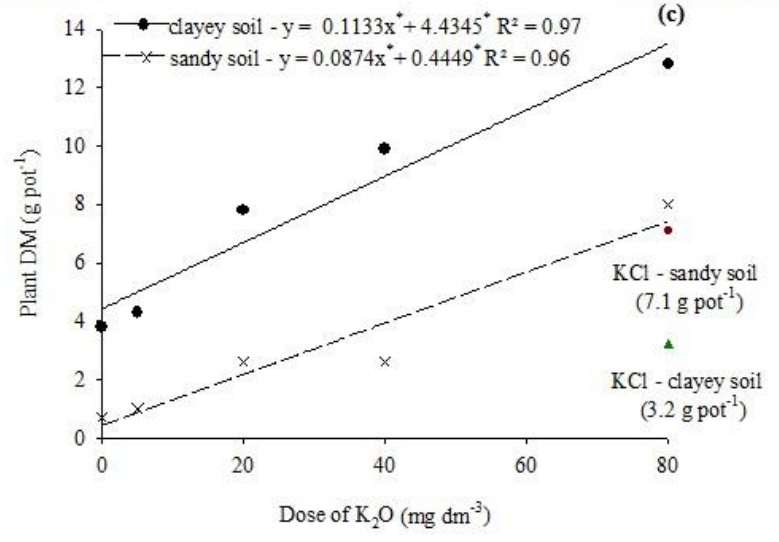

Fig 1. Urochloa brizantha plant dry matter (DM) at 68 (a), 104 (b) and 168 (c) days after sowing with increasing doses of glauconitic siltstone applied in clayey and sandy soils. Square and triangles symbols refer to the $\mathrm{KCl}$ treatment applied at the dose of $80 \mathrm{mg} \mathrm{dm}$ ${ }^{3}$ of $\mathrm{K}_{2} \mathrm{O}$ in clayey and sandy soils, respectively.

Table 2. Soils chemical and physical properties.

\begin{tabular}{|c|c|c|c|c|c|c|c|c|c|c|c|c|c|}
\hline \multirow{2}{*}{ Soil } & \multirow[t]{2}{*}{$\mathrm{pH}$} & $\mathrm{Si}$ & K & $P$ & $\mathrm{Al}^{+3}$ & $\mathrm{Ca}^{2+}$ & $\mathrm{Mg}^{2+}$ & OM & SB & $\mathrm{T}$ & sand & silt & clay \\
\hline & & \multicolumn{3}{|c|}{$---m g ~ d m^{-3}---$} & \multicolumn{3}{|c|}{$---\mathrm{cmol}_{\mathrm{c}} \mathrm{dm}^{-3}---$} & \multicolumn{6}{|c|}{---- $\mathrm{g} \mathrm{dm}^{-3}$} \\
\hline Typic Dystrustox & 3.8 & 5.6 & 18.6 & 0.2 & 0.8 & 0.6 & 0.1 & 8.9 & 7.5 & 33 & 210 & 100 & 690 \\
\hline Typic Quartzipsamment & 3.6 & 2.6 & 8.1 & 3.1 & 0.9 & 0.6 & 0.1 & 9.9 & 7 & 35 & 900 & 10 & 90 \\
\hline
\end{tabular}

Soil pH: 1:2.5 soil sample/water ratio; Si: $\mathrm{CaCl}_{2} 0.01 \mathrm{~mol} \mathrm{~L}^{-1}$. Available $\mathrm{K}$ and P: Mehlich-1 method $\left(\mathrm{HCl} 0.05 \mathrm{~mol} \mathrm{~L}^{-1}+\mathrm{H}_{2} \mathrm{SO}_{4} 0.0125 \mathrm{~mol} \mathrm{~L}{ }^{-1}\right)$. Exchangeable Al, Ca and Mg: KC $1 \mathrm{~mol} \mathrm{~L}{ }^{-1}$. OM: potassium dichromate $\left(\mathrm{K}_{2} \mathrm{Cr}_{2} \mathrm{O}_{7}\right)$ method. SB: sum of bases. T: cation. 


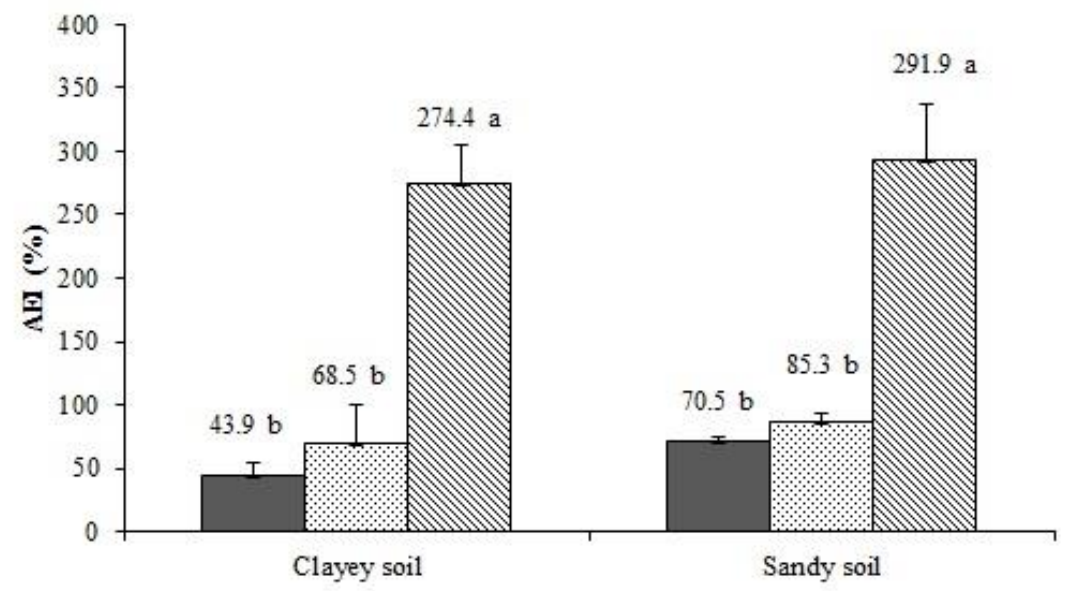

Fig 2. Agronomic efficiency index (AEI) of the glauconitic siltstone in relation to $\mathrm{KCl}$ in clayey and sandy soils at 68,104 and 168 days after sowing. Different letters within each column group denote significant difference between treatments. Least Significant Difference (LSD): Clayey soil: 172.03; Sandy soil: 205.41 . Values higher than $100 \%$ denote superiority of the GS in relation to $\mathrm{KCl}$ treatment.

(a)
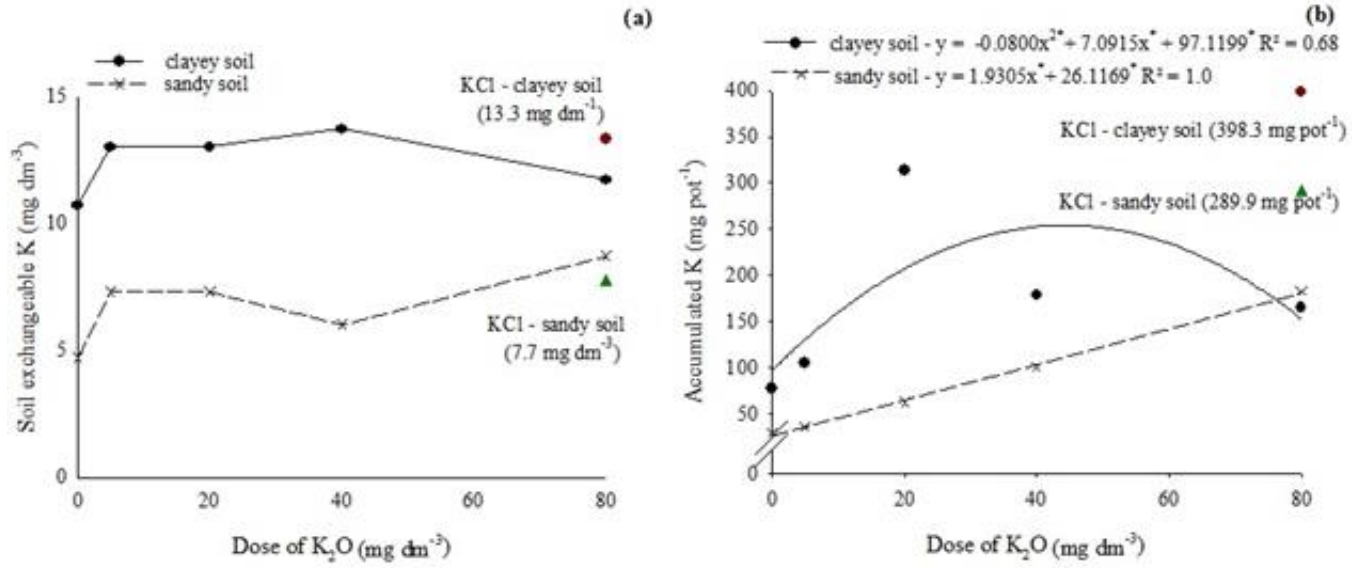

(c)
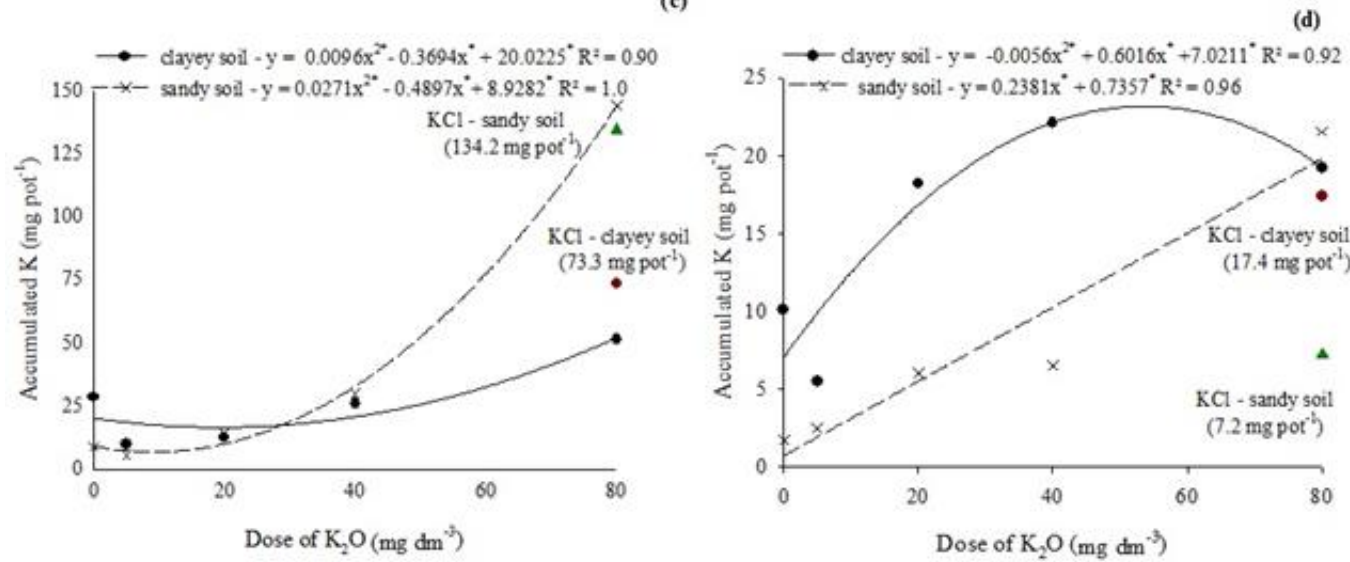

Fig 3. Soil exchangeable K (a) and K accumulated in Urochloa brizantha plants at 68 (b), 104 (c) and 168 (d) days after sowing with increasing doses of glauconitic siltstone applied in clayey and sandy soils. Square and triangles symbols refer to the $\mathrm{KCl}$ treatment applied at the dose of $80 \mathrm{mg} \mathrm{dm}^{-3}$ of $\mathrm{K}_{2} \mathrm{O}$ in clayey and sandy soils, respectively 

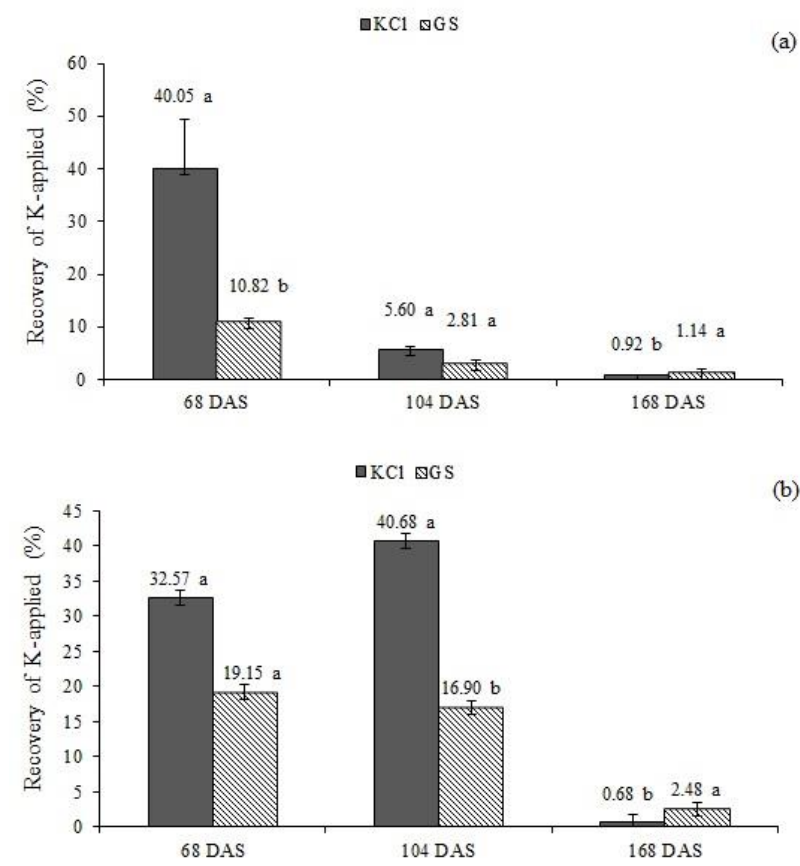

Fig 4. Recovery of K-applied (\%) from Urochloa brizantha plants after glauconitic siltstone application in clayey (a) and sandy (b) soils. Different letters within each column group denote significant difference between treatments. Least Significant Difference Clayey soil: 68 DAS: 17.73; 104 DAS: 7.33; 168 DAS: 0.20. Sandy soil: 68 DAS: $18.48 ; 104$ DAS: 11.03; 168 DAS: 1.65.

(a)

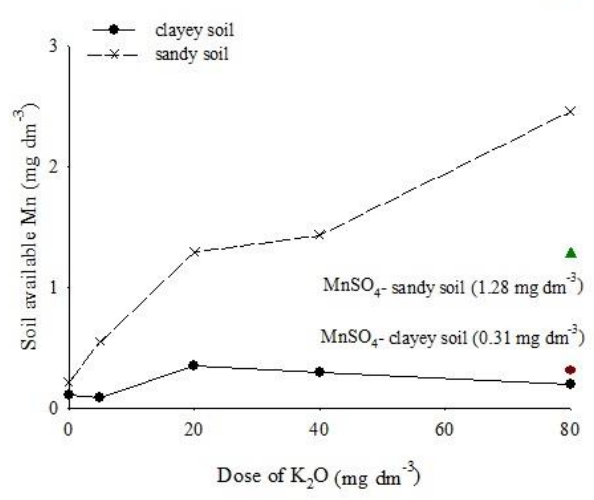

(c)

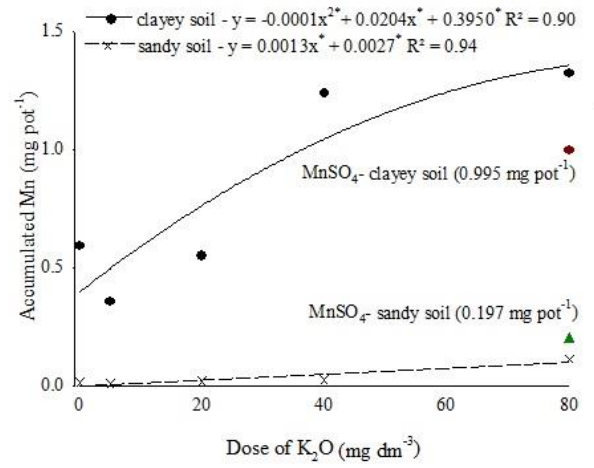

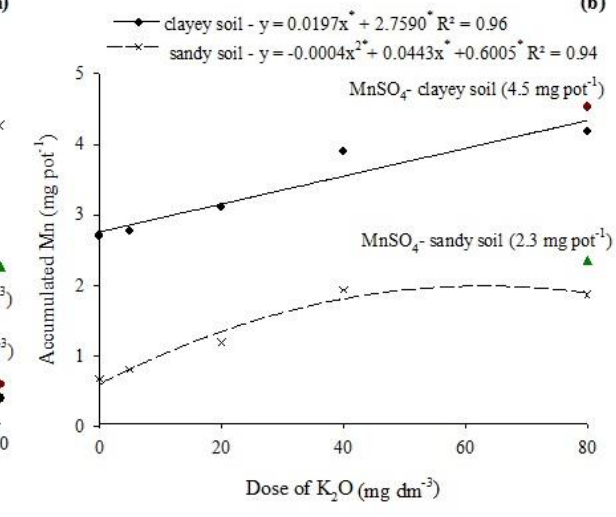

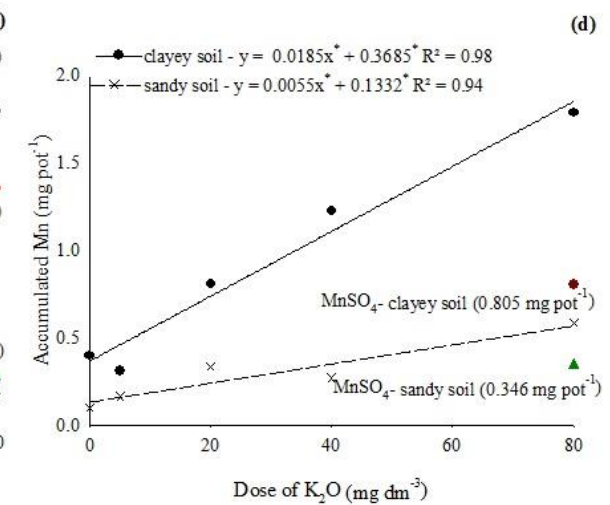

Fig 5. Soil available Si (a) and Si accumulated in Urochloa brizantha plants at 68 (b), 104 (c) and 168 (d) days after sowing with increasing doses of glauconitic siltstone applied in clayey and sandy soils. Square and triangles symbols refer to the Wollas tonite treatment applied at the dose of $270 \mathrm{mg} \mathrm{dm}^{-3}$ of $\mathrm{Si}$ in clayey and sandy soils, respectively. 

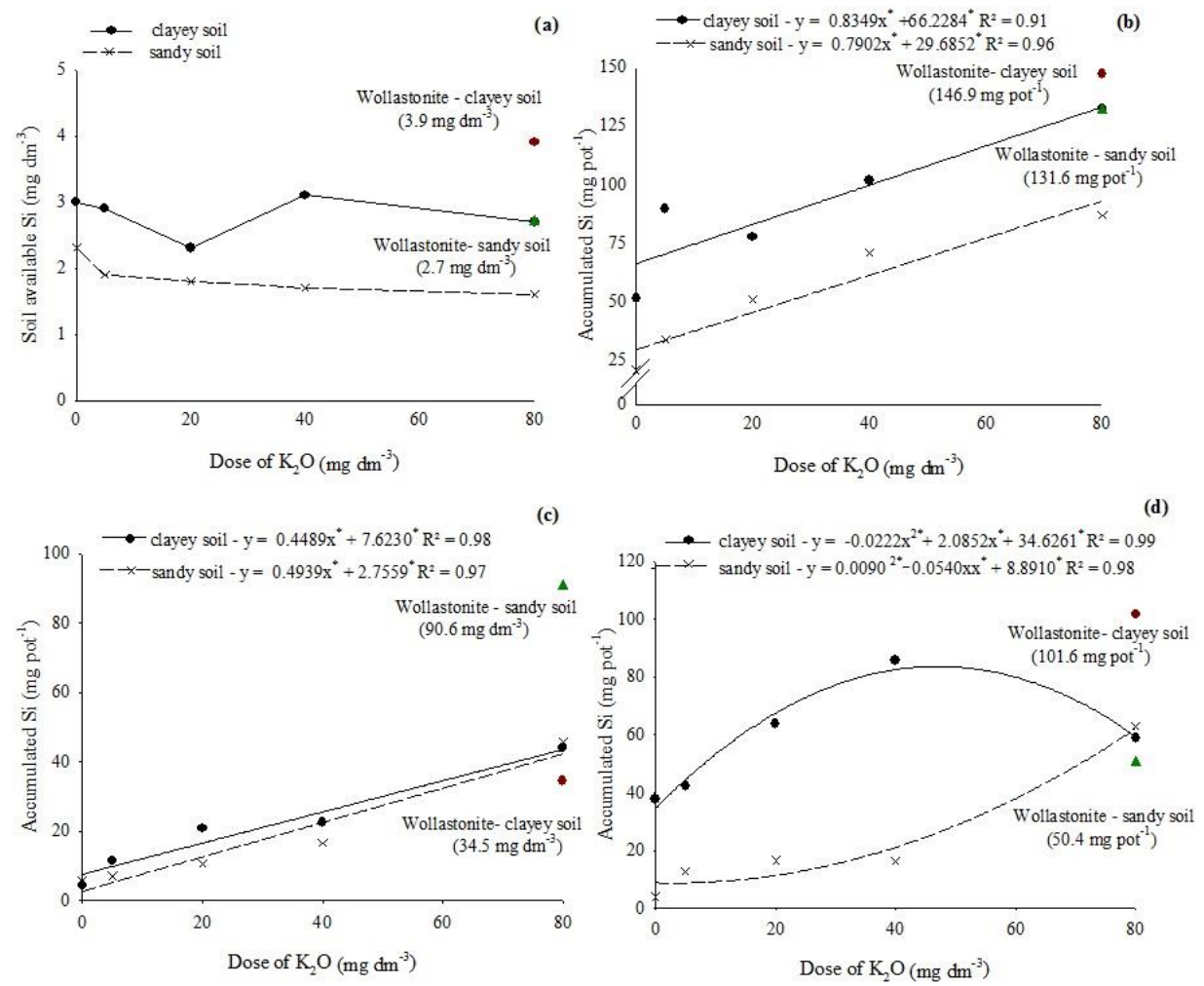

Fig 6. Soil available Mn (a) and Mn accumulated in Urochloa brizantha plants at 68 (b), 104 (c) and 168 (d) days after sowing with increasing doses of glauconitic siltstone applied in clayey and sandy soils. Square and triangles symbols refer to the $\mathrm{MnSO}_{4}$ treatment applied at the dose of $2 \mathrm{mg} \mathrm{dm}^{-3}$ of $\mathrm{Mn}$ in clayey and sandy soils, respectively.

exchange capacity at $\mathrm{pH}$ 7. In general, owing the capability of the GS to supply $\mathrm{K}, \mathrm{Si}$ and $\mathrm{Mn}$ to Urochloa brizantha plants, especially after consecutive crop cycles, these results propose an innovative and sustainable use of nutrient-rich rock to improve tropical pasture areas and increase cattle production.

\section{Materials and Methods}

\section{Product characterization}

The glauconitic siltstone (GS) is originated from the state of Minas Gerais, Brazil, presenting low salinity $\left(1.7 \mathrm{~g} \mathrm{dm}^{-3}\right)$, silicate rock with quartz feldspar, albite, white micas, and relatively high concentrations of glauconitic $\left(25 \mathrm{dag} \mathrm{dm}^{-3}\right)$. In addition to the rock powder, standard sources of $\mathrm{K}_{2} \mathrm{O}(\mathrm{KCl})$, $\mathrm{Si}$ (Wollastonite) and $\mathrm{Mn}\left(\mathrm{MnSO}_{4}\right)$ were used for comparison purposes. The chemical composition of the glauconitic siltstone as well as $\mathrm{KCl}$, Wollastonite, and $\mathrm{MnSO}_{4}$ is shown in Table 1. All treatments were applied to soil as a $<2 \mathrm{~mm}$ powder.

\section{Experiment conduction}

Two experiments were carried out under greenhouse conditions from 09/07/2016 to 02/21/2017, one using a clayey soil and the other, a sandy soil. The samples of the two different soils types were collected at $0-20 \mathrm{~cm}$ depth in the state of Minas Gerais, Brazil, being classified according to U. S. Department of Agriculture soil taxonomy (USDA,
1999) as Typic Dystrustox (clayey soil) and a Typic Quartzipsamment (sandy soil), which physical and chemical properties are described in Table 2.

Both experiments were arranged in a completely randomized design with one factor, i.e., GS doses, and four replications. Five $\mathrm{GS}$ doses $\left(0,5,20,40\right.$, and $80 \mathrm{mg} \mathrm{dm}^{-3}$ of $\mathrm{K}_{2} \mathrm{O}$ ) were applied, resulting in four Si and $\mathrm{Mn}$ doses (270, 1080,2160 , and $4320 \mathrm{mg} \mathrm{dm}^{-3}$ of Si; $0.5,2.0,4.0$, and $8.0 \mathrm{mg}$ $\mathrm{dm}^{-3}$ of $\mathrm{Mn}$ ). In addition, $\mathrm{KCl}$, Wollastonite and $\mathrm{MnSO}_{4}$ were used as additional treatments at doses of $80 \mathrm{mg} \mathrm{dm}^{-3}$ of $\mathrm{K}_{2} \mathrm{O}$, $270 \mathrm{mg} \mathrm{dm}^{-3}$ of $\mathrm{Si}$ and $2 \mathrm{mg} \mathrm{dm}^{-3}$ of $\mathrm{Mn}$, respectively, resulting in 32 pots for each soil type. The treatments were incubated for 60 days in $5 \mathrm{dm}^{-3}$ of the two soil types (clayey and sandy soils) and soil moisture was controlled by daily weighing, replacing the volume lost through evapotranspiration with deionized water.

After the incubation period, $200 \mathrm{mg} \mathrm{kg}^{-1}$ of $\mathrm{N}$ and $400 \mathrm{mg} \mathrm{kg}$ ${ }^{1}$ of $\mathrm{P}_{2} \mathrm{O}_{5}$ were added to samples through the ammonium sulfate $\left(\left(\mathrm{NH}_{4}\right)_{2} \mathrm{SO}_{4}\right)$ and triple superphosphate, respectively. Micronutrients were also supplied adding 1.5, 5.0, 0.5, and $0.05 \mathrm{mg} \mathrm{dm}^{-3}$ of $\mathrm{Cu}, \mathrm{Zn}, \mathrm{B}$, and $\mathrm{Mo}$ through $\mathrm{CuSO}_{4} \cdot 5 \mathrm{H}_{2} \mathrm{O}$, $\mathrm{ZnSO}_{4} .7 \mathrm{H}_{2} \mathrm{O}, \mathrm{H}_{3} \mathrm{BO}_{3}$ and $\left(\mathrm{NH}_{4}\right) 6 \mathrm{Mo}_{7} \mathrm{O}_{24} \cdot 4 \mathrm{H}_{2} \mathrm{O}$, respectively. Ten seeds of Urochloa brizantha cv. Marandú (Syn. Brachiaria brizantha) were sown per pot, at a depth of $2 \mathrm{~cm}$. After the emergence of the seedlings, thinning was carried out, maintaining five plants per pot.

At $30,40,65$, and 82 DAS, ammonium sulfate was applied providing $50 \mathrm{mg} \mathrm{kg}^{-1}$ of $\mathrm{N}$. Daily irrigation was done as well as periodic observations to evaluate the possible incidence of pests and plant diseases in Urochloa brizantha cultivation. 


\section{Plant and soil analysis}

Three Urochloa brizantha plant cuts were performed at $4 \mathrm{~cm}$ above ground level at 68, 104 and 168 DAS. After the third plant cut, soil samples were also collected. The plant samples were washed, dried in an oven and weighed to obtain values of dry matter of the aerial part (DM). Afterwards, the samples were ground and submitted to nitric-perchloric digestion (Johnson and Ulrich, 1959) and K and $\mathrm{Mn}$ levels were analyzed by colorimetric method (Murphy and Riley, 1962). The plant samples were also submitted to $\mathrm{Si}$ analysis following a methodology proposed by Korndörfer et al. (2004). The levels of nutrients in the aerial part were converted to accumulated levels using the DM values, obtaining values in $\mathrm{mg} \mathrm{pot}^{-1}$. The soil samples were dried and submitted to $\mathrm{K}$ and $\mathrm{Mn}$ analysis, using the methodology proposed in the Embrapa's Manual of Methods (Donagema et al., 2011), and Si analysis, according to Korndörfer et al. (2004).

Using the nutrient accumulated values, agronomic efficiency index (AEI) of the GS relative to $\mathrm{KCl}$ was calculated using the equation proposed by Fageria et al. (2010) as bellow:

AEI $(\%)=\frac{\text { GS DM-Control DM }}{\mathrm{KCl} \text { DM-Control DM }} \times 100$

Where GSDM is the plant DM with the application of the GS ( $80 \mathrm{mg} \mathrm{dm}{ }^{-3}$ of $\mathrm{K}_{2} \mathrm{O}$ ), $\mathrm{KCl} \mathrm{DM}$ is the plant DM with the application of $\mathrm{KCl}\left(80 \mathrm{mg} \mathrm{dm}^{-3}\right.$ of $\left.\mathrm{K}_{2} \mathrm{O}\right)$ and the control DM is the plant $\mathrm{DM}$ in the additional control treatment without $\mathrm{K}_{2} \mathrm{O}$ application $\left(0 \mathrm{mg} \mathrm{dm}^{-3}\right.$ of $\mathrm{K}_{2} \mathrm{O}$ ). In addition to AEI, the recovery of $\mathrm{K}$-applied was also calculated through the follow equation:

Recovery of K-applied (\%) $=\frac{\text { GS K }- \text { Control K }}{\mathrm{K} \text { applied }} \times 100$

Where; GS K is the mean value of $\mathrm{K}$ accumulated in plants cultivated with the application of $80 \mathrm{mg} \mathrm{dm}^{-3}$ of $\mathrm{K}_{2} \mathrm{O}$ of GS, control $\mathrm{K}$ is the mean value of $\mathrm{K}$ accumulated in plants cultivated in the control treatment without $\mathrm{K}_{2} \mathrm{O}$ application ( $0 \mathrm{mg} \mathrm{dm}^{-3}$ of $\mathrm{K}_{2} \mathrm{O}$ ) and $\mathrm{K}$ applied is the amount of $\mathrm{K}$ applied at the dose of $80 \mathrm{mg} \mathrm{dm}^{-3}$ of $\mathrm{K}_{2} \mathrm{O}$ (Fageria et al., 2010).

\section{Statistical analysis}

Normality test was applied to verify if the data had a normal distribution. All results showed normal distribution. Then, data was submitted to regression analysis $(p<0.05)$, using SigmaPlot software ( $11^{\text {th }}$ edition). Means of AEI and recovery of K-applied values were submitted to "least significant difference" $\left(\right.$ LSD) test $(p<0.05)$ using Sisvar software $\left(5^{\text {th }}\right.$ edition).

\section{Conclusion}

The application of the glauconitic siltstone in tropical soils promoted increases in Urochloa brizantha plant dry matter, as well as $\mathrm{K}, \mathrm{Si}$ and $\mathrm{Mn}$ levels in soil samples and accumulated in plants. In general, greater effects following the application of the glauconitic siltstone fertilizer were obtained after consecutive cropping cycles due to its medium to long-term release. Results described in this study provide an important understanding of the use of natural nutrient rich-rocks as multi-nutrient fertilizers in tropical soils, being an efficient alternative to improve soil fertility and increase tropical pasture productivity.

\section{Acknowledgments}

The authors are grateful to the Brazilian National Council for Scientific and Technological Development (CNPq), the Coordination of Improvement of Higher Level Personnel (CAPES) and the Foundation of Support Research of the State of Minas Gerais (FAPEMIG) for financial support and scholarships. We also acknowledge the support of the Verde AgriTech Company.

\section{References}

Asner GP, Elmore AJ, Olander LP, Martin RE, Harris AT (2004) Grazing systems, ecosystem responses, and global change. Annu Rev Environ Resour. 29:261-299.

Bonfim-da-Silva EM \& Monteiro FA (2006) Nitrogen and sulphur for productive characteristics of signalgrass from degrading pasture area. Rev Bras Zootec. 35:1289-1297.

Burnell JN (1988) The biochemistry of manganese in plants. In: Graham RD, Hannam RJ, Uren NJ (eds). Manganese in Soil and Plants. Kluwer Academic Publishers, Dordrecht, Netherlands.

Cerri CC, Moreira CS, Alves PA, Raucci GS, Castigioni BA, Mello FFC, Cerri DGP, Cerri CEP (2016) Assessing the carbon footprint of beef cattle in Brazil: a case study with 22 farms in the State of Mato Grosso. J Clean Prod. 112:2593-2600.

Cruz JL, Pelacani CR, Coelho EF, Caldas RC, Almeida AQ, Queiroz JR (2006) Influence of $\mathrm{NaCl}$ salinity on uptake and distribution of sodium, chloride and macronutrients in yellow passion fruit seedlings. Bragantina. 65:275-284.

Dias-Filho MB (2014) Diagnóstico das pastagens no Brasil. 1.ed. Belém: Embrapa Amazônia. 36p. Available: https://www.infoteca.cnptia.embrapa.br/bitstream/doc/9 86147/1/DOC402.pdf Accessed 01 May 2018

Donagema GK, Campos DVB, Calderano SB, Teixeira WG, Viana JHM (2011) Manual de métodos de análise de solos. Embrapa Solos, Rio de Janeiro, Brazil.

Fageria NK, Santos AB, Moraes MF (2010) Yield, potassium uptake, and use efficiency in upland rice genotypes. Commun Soil Sci Plant. 41:2676-2684.

Fonte SJ, Nesper M, Hegglin D, Velásquez JE, Ramirez B, Rao IM, Bernasconi SM, Bünemann EK, Frossard E, Oberson A (2014) Pasture degradation impacts soil phosphorus storage via changes to aggregate-associated soil organic matter in highly weathered tropical soils. Soil Biol Biochem. 68:150-157.

Gamero RMP, Torrado PV, Ferreira TO (2004) Mineralogy and physical chemistry of mangrove Soils from Iriri river at the bertioga channel. Rev Bras Cienc Solo. 28(4): 233-243.

Geman H (2015) Agricultural finance: from crops to land, water and infrastructure. John Wiley \& Sons, New Jersey.

Johnson CM, Ulrich A (1959) Analytical methods for use in plants analyses (Bulletin, 766). Unversity of California, Los Angeles.

Keeping MG (2017) Uptake of silicon by sugarcane from applied sources may not reflect plant-available soil silicon and total silicon content of sources. Front Plant Sci. 8:760.

Korndörfer GH, Pereira HS, Nola A (2004) Análise de silício: solo, planta e fertilizante. UFU-GPSi-ICIAG. Available: http://www.nutricaodeplantas.agr.br/site/downloads/bt2 _gpsi.pdf. Accessed 20 April 2018. 
Lorentzen EML and Kingston HM (1996) Comparison of microwave-assisted and conventional leaching using EPA method 3050B. Anal Chem. 68:4316-4320.

Ma JF, Takahashi E (2002) Soil, Fertilizer, and Plant Silicon Research in Japan. Elsevier Science, Amsterdam.

Martins V, Gonçalves ASF, Marchi G, Guilherme LRG, Martins EDS (2015) Potassium solubilization in verdete and limestone mixtures treated thermochemically. Pesq Agropec Trop. 45(1):66-72.

Meena VD, Rajendiran S, Dotaniya ML, Kundu AS, Coumar V, Rao AS (2014) A case for silicon fertilization to improve crop yields in tropical soils. Proc Natl Acad Sci India Sect B Biol Sci. 84(3):505-518.

Miles JW, do Valle CB, Rao IM, Euclides VPB (2004) Brachiaria grasses. In: Sollenberger LE, Moser L \& Burson B (ed) Warm-season (C4) grasses, ASA: CSSA: SSSA, Madison. Ministério da Agricultura, Pecuária e Abastecimento (MAPA) (2007) Manual de métodos analíticos oficiais para fertilizantes minerais, orgânicos, organominerais e corretivos. Brasília: MAPA. Available: http://www.agricultura.pr.gov.br/arquivos/File/PDF/in_28 _07_anexo.pdf Accessed 10 April 2018.

Murphy J, Riley JP (1962) A modified single-solution method for the determination of phosphate in natural waters. Anal Chem Acta. 27:31-36.

Oliveira M, Leite A, Wender I (2017) Ultrapotassic syenites: an alternative k-source worldwide. Paper presented at the 2nd International Workshop on Alternative Potash. Newcastle University, 15 June 2017.
Peron AJ and Evangelista AR (2004) Pasture degradation in savanna's regions. Ciênc Agrotec. 28(3):655-661.

Prakash S, Verma JP (2016) Global perspective of potash for fertilizer production. In: Meena VS, Maurya BR, Verma JP, Meena RS (eds) Potassium solubilizing microorganisms for sustainable agriculture. Springer, India.

Resende AV, Martins ES, Oliveira CG, Sena MC, Machado CTT, Kinpara DI, Oliveira Filho EC (2006) Suprimento de potássio e pesquisa de uso de rochas "in natura" na agricultura brasileira. Esp Geog. 9:19-42.

Silva MAG, Boaretto AE, Fernandes HG, Scivittaro WB (2001) Efeito do cloreto de potássio na salinidade de um solo cultivado com pimentão, Capsicum annuum L., em ambiente protegido. Acta Sci. 23:1085-1089.

Twyman ES (1951) The iron and manganese requirements of plants. New Phytol. 50(2):210-226.

Ubavić, M., Marković, M., \& Oljaĉa, R. (2008). Mikroelementi I mikrođubriva i njihova primena u praksi. Banja Luka: University of Banja Luka, Faculty of Agriculture.

USDA Soil Taxononmy (1999) A basic system of soil classification for making and interpreting soil survey, 2 nd ed. USDA, Washington, DC.

Yamada T \& Roberts TL (2005) Potássio na agricultura Brasileira. Potafos, Piracicaba. 263p.

Zörb C, Senbayram M, Peiter E (2014) Potassium in agriculture - status and perspectives. J Plant Physiol. 171:656-669. 